Journal of Animal and Veterinary Advances 9 (13): 1848-1851, 2010

ISSN: $1680-5593$

(C) Medwell Journals, 2010

\title{
The Effects of Body Weight, Body Condition Score, Age, Lactation, Serum Trygliceride, Cholesterol and Paraoxanase Levels on Pregnancy Rate of Saanen Goats in Breeding Season
}

\author{
${ }^{1}$ Ilker Serin, ${ }^{2}$ Gunes Serin, ${ }^{3}$ Murat Yilmaz, ${ }^{4}$ Funda Kiral and ${ }^{1}$ Ahmet Ceylan \\ ${ }^{1}$ Department of Reproduction and Artificial Insemination, Faculty of Veterinary Medicine, \\ ${ }^{2}$ Department of Obstetrics and Gynecology, ${ }^{3}$ Department of Animal Science, \\ ${ }^{4}$ Department of Biochemistry, Faculty of Agriculture, \\ Adnan Menderes University, Aydin, Turkey
}

\begin{abstract}
The purpose of this study was to determine the relationship between pregnancy rate and body weight, Body Condition Score (BCS), age, lactation, serum triglyceride, cholesterol and paraoxanase levels of Saanen goats in breeding season. Data were obtained from 55 Saanen does under kept semi-extensive conditions. For estrus synchronization, vaginal sponges containing $40 \mathrm{mg}$ Fluorogestone Acetate (FGA) were applied for 14 days and $500 \mathrm{IU}$ equine gonadotropin hormone (eCG) was injected on the day of vaginal sponges removed. Blood samples were collected from vena jugularis also body weights, body condition scores (5-point scale), ages and lactation status of all goats were recorded at the time of sponges removed. Estrus detection was performed with teaser buck at $48 \mathrm{~h}$ after removal of the sponges. All does in estrus were mated with fertile bucks. After 12th day of post-mating, $4 \mu \mathrm{g}$ gonadorelin was injected intramuscularly for enhance luteal function. Pregnancy diagnosis was performed by transrectal ultrasonography at 40th day of post-mating. The relationship between pregnancy rates and body weight, BCS, age, lactation, blood triglyceride, cholesterol and paraoxanase levels at mating day were statistically analyzed. The body weight and BCS were significantly effected the pregnancy rates $(\mathrm{p}<0.05)$ but there were no relation between pregnancy rate and other parameters ( $p>0.05$ ). It is concluded that body weight and BCS has a significant effect on fertility of Saanen goats during breeding season and the necessity of using higher energy feeding in goats with lower BCS and weight before breeding season.
\end{abstract}

Key words: Pregnancy rate, body condition, triglyceride, cholesterol, PON1, goats

\section{INTRODUCTION}

Estrus synchronization has been successfully and widely used before naturally mating, artificially insemination and embryo transfer programs in goats. The most commonly synchronization method is the vaginal sponges containing FGA for 14 days and combination with PMSG at withdrawal of sponges which is also successful during the breeding season in goats (Whitley and Jackson, 2004).

In addition to estrus synchronization, alternative hormonal applications are need to enhance the reproductive success in herds with low performance. Another cause of infertility in small ruminant reproduction is the inadequate luteal function which is very important for maternal recognition of pregnancy. This problem can be treated successfully by the use of GnRH analogues for to enhance the luteal function in goats (Alacam et al.,
1999; Cam and Kuran, 2004; Uslu and Gulyuz, 2009). It is well known that non-infectious factors such as nutrition, live weight and body condition are important factor on reproductive performance of farm animals (Robinson, 1990; Downing and Scaramuzzi, 1991). There are many studies investigate the effect of BCS (Molina et al., 1994; Atti et al., 2001; Mellado et al., 2006; Madani et al., 2009), energy/protein intake (Hussain et al., 1996; Meza-Herrera et al., 2008), serum lipids and metabolite levels (Valocky and Posivak, 1998; Mellado et al., 2004; Ceylan et al., 2007; Samarutel et al., 2008) and milk yield (Mellado et al., 1996) on reproductive performance of cows, sheepand goats. Besides there is limited available data about these parameters in Saanen goat breeding in Turkey.

Recently, Paraoxanase (PON1) activity in cows under different metabolic status has been investigated by some researchers. PON1 is known as associate with $\mathrm{HDL}$

Corresponding Author: Ilker Serin, Department of Reproduction and Artificial Insemination, Faculty of Veterinary Medicine, Adnan Menderes University, Turkey 
(La Du et al., 1999) synthesized and secreted by liver Turk et al. (2004) demonstrated that serum Paraoxanase (PON1) activity was reduced in early postpartum dairy cows. Therefore, there is a possibility that serum PON1 activity is a useful indicator for diagnosis of diseases in this period or for antioxidative capacity in serum. However, knowledge about serum PON1 activity in veterinary medicine is still scarce (Turk et al., 2004, 2005, 2008; Bionaz et al., 2007) and there is no information relationship between PON1 activity and reproductive performance in goat.

The southwest region of Turkey has an important role in goat production especially Saanen breed have been increased for last years. Several studies including fertility data in Saanen does have been recorded (Alacam et al., 1985; Oliveira et al., 2001; Velizet al., 2009) but there is limited report investigate the relationship between fertility and body condition at mating. The objective of the present study was to determine the effects of $\mathrm{BCS}$, body weight, age, lactation, serum triglyceride, cholesterol and paraoxanase activity at mating on pregnancy rate of Saanen goats in breeding season.

\section{MATERIALS AND METHODS}

The study was carried in a dairy goat farm located Aydin province of Turkey in breeding season. About 55 nulliparous and multiparous Saanen goats with different ages were selected following an abdominal and transrectal ultrasonic examination before sponge insertion in order to identify pregnant and pseudo-pregnant goats which were not included in the protocol.

BCS were estimated by the same observer according to 5-point scale for all females at the end of synchronization protocol. Body weights were recorded by using weigher, ages and lactation status were obtained from farm records and attendants. Estrus was synchronized by the use of intravaginal sponges containing $40 \mathrm{mg}$ FGA (Chronogest ${ }^{7}$-Intervet, Istanbul, Turkey) in September which is the natural breeding season for goats in this region.

The intravaginal sponges were inserted into vagina of each goat for 14 days. At the day of sponge withdrawal, 500 IU ECG (Chronogest'-Intervet, Istanbul, Turkey) were injected intramuscularly for enhance of estrus symptoms and ovulation. Estrus detection was performed with teaser buck at $48 \mathrm{~h}$ after removal of the sponges. Estrus was defined as acceptance of mounting. Goats in estrus $(n=55)$ were allowed to mate with fertile bucks twice during estrus. Day of estrus was designated as day 0 (day of mating). At 12th day, $4 \mu \mathrm{g}$ of synthetic
GnRH agonist (Buserelin, Receptal, Topkim 7, Istanbul, Turkey) was injected intramuscularly for enhance luteal function. Pregnancy diagnosis was performed between days 30-40th using real time transrectal ultrasonography (MyLab Vet30-ESAOTE', Italy) with $7.5 \mathrm{MHz}$ linear transducer.

Blood samples were collected from vena jugularis by using vacuum Gree-Vac-Tube7 tubes (Standard Plus and Medical, Sun-Dong, Korea) after first mating. Blood samples were allowed to clot, the serum aspirated and stored at $-20^{\circ} \mathrm{C}$ until their analyses for cholesterol, triglyceride and PON1. The enzyme activities of PON1 were assayed according to the method described by Eckerson et al. (1983). Briefly, paraoxonose activity was measured using paraoxone as substrate. The reaction mixture included $1 \mathrm{Mm}$ paraoxone, $1 \mathrm{MNaCl}$ and $1 \mathrm{mMCaCl}$ in $50 \mathrm{mM}$ glycine- $\mathrm{NaOH}$ buffer $(\mathrm{pH} ; 10.5)$. The reaction was initiated by the addition of $5 \mu \mathrm{L}$ the sample to the reaction mixture and monitored at $25^{\circ} \mathrm{C}$. The serum levels of triglycerides, total cholesterol were determined using commercial available assay kits (Archem, Turkey) with a spectrophotometer (Shimadzu, UV-1601). The analyses were carried out according to the manufacturers instructions.

Data were compared by calculating means, standard mean errors and the significant of differences. Differences between the groups were investigated by $\chi^{2}$-test for pregnancy rate. $\mathrm{p}<0.05$ were considered as significant.

\section{RESULTS AND DISCUSSION}

Out of the 34, 55 goats were determined as pregnant and the conception rate was $61.8 \%$ in the present study. The Chi-square tests revealed that the body weight $(37.60 \pm 1.55 \mathrm{~kg})$ and $\mathrm{BCS}(1.70 \pm 0.07)$ of pregnant goats was significantly higher $(\mathrm{p}<0.05)$ than that of the non-pregnant goats $(32.69 \pm 1.72$ and $1.45 \pm 0.09 \mathrm{~kg})$ in study. There was no significant difference between age, lactation, triglyceride, cholesterol and PON1 values in pregnant and non pregnant goats $(\mathrm{p}>0.05)$. The mean values of body weight, BCS, age, lactation and biochemical parameters were shown in Table 1.

Table 1: Body weight, BCS, age, lactation, blood triglyceride, cholesterol and PON1 values of the pregnant and non-pregnant goats

\begin{tabular}{|c|c|c|c|}
\hline$\underline{\text { Parameters }}$ & $\begin{array}{l}\text { Pregnant } \\
(\mathrm{n}=34)\end{array}$ & $\begin{array}{l}\text { Non-pregnant } \\
(\mathrm{n}=21)\end{array}$ & $\mathrm{p}$-values \\
\hline Body weight (kg) & $37.60 \pm 1.55$ & $32.69 \pm 1.72$ & $<0.05$ \\
\hline BCS (5-point scale) & $1.70 \pm 0.75$ & $1.45 \pm 0.97$ & $<0.05$ \\
\hline Age (y ear) & $3.19 \pm 0.29$ & $2.57 \pm 0.27$ & NS \\
\hline Lactation $(1 / 0)$ & $1.38 \pm 0.85$ & $1.43 \pm 0.11$ & NS \\
\hline Trigly ceride $\left(\mathrm{mmol} \mathrm{L}^{-1}\right)$ & $0.54 \pm 0.03$ & $0.52 \pm 0.03$ & NS \\
\hline Cholesterol $\left(\mathrm{mmol} \mathrm{L}^{-1}\right)$ & $1.96 \pm 0.09$ & $1.93 \pm 0.16$ & NS \\
\hline PON1 (IU mL $\left.{ }^{-1}\right)$ & $464.35 \pm 26.33$ & $493 \pm 41.8$ & NS \\
\hline
\end{tabular}

NS: Non-Significant 
It is reported that the fertility and prolificacy are affected by BCS and body weight of ewes at mating (Molina et al., 1994; Mellado et al., 2004; Madani et al., 2009) in breeding and non-breeding season. Hussain et al. (1996) have shown that low energy intake or Body Condition Score (BCS) causes decreasing of fertility. Mellado et al. (1996) reported that kidding rates of goats having $\mathrm{BCS} 3$ were around $20 \%$ lower than rates of goats having $\mathrm{BCS} 4$ or greater. Additionally, Meza-Herrera et al. (2008) documented that does with higher BCS have more CL than does with lower condition. Atti et al. (2001) observed higher fertility in Barbarine ewes which has $\mathrm{BCS}(>1.5)$ and body weight $(>35 \mathrm{~kg})$ at the beginning of mating period. In current study, BCS of pregnant goats was higher than that of non-pregnant Saanen goats $(\mathrm{p}<0.05)$. This result shows that in order to obtain higher pregnancy rate in Saanen goats, nutritional improving must be performed for goats having low BCS in pre-mating period and $\mathrm{BCS}$ at mating must be $\geq 1.5$. Another important factor affecting pregnancy rate was body weight of goats. Regarding to the mean body weight of pregnant and non-pregnant goats, the threshold value of body weight for successful breeding program may be determined as $35 \mathrm{~kg}$ for Saanen goats. This data are accordingly with Atti et al. (2001)'s study result.

The relationship between serum cholesterol and fertility has been investigated by several researchers. Miura et al. (2008) reported that the serum cholesterol concentration is higher in pregnant cows than that of non-pregnant cows following estrus synchronization by using progesterone implants. Besides, Samarutel et al. (2008) reported that serum cholesterol concentrations are significantly higher in the cows with some ovarian disorders than healthy cows. Westwood et al. (2002) have found positive association between cholesterol levels and reproductive performance in cows. In present study, there is no significant difference between pregnant and non-pregnant goats $(p>0.05)$. Besides, there was no significant effect of age and lactation status of goats in present investigation, further studies carried on flocks consist of much more goats may help for revealing the more detailed data.

Recently, some researchers reported that the serum PON1 levels change significantly in cows during periparturient period (Turk et al., 2004, 2005; Bionaz et al. 2007). Turk et al. (2004) also reported that a decreased serum PON1 activity associated with lipid parameters changes in cows during early postpartum period. In addition, serum triglyceride and cholesterol levels were markedly reduced in the same period. Bionaz et al. (2007) also found lower PON1 activity in transition dairy cows. However, in the present study, the serum PON1 concentration and serum lipids showed no significant difference between pregnant and non-pregnant groups. To the researchers knowledge, there are no reports regarding the effect of serum PON1 levels on fertility of goats in breeding season. In further studies regarding relationship between lipid metabolism and PON1 activity in female goats are needed.

\section{CONCLUSION}

In this study, these results demonstrated that a low body weight $(<35 \mathrm{~kg})$ and $\mathrm{BCS}(<1.5)$ at the start of the breeding period caused the low conception rate. The nutrition program of goats with lower BCS should be reassessed and supported with the higher energy feed before breeding season for improving herd fertility.

\section{REFERENCES}

Alacam, E., B. Guven, A. Ayar and E. Saban, 1999. Ankara keçilerinde gonadorelin uygulamalarinin kan progesterone ostradiol 17- $\beta$ duzeyleri ile bazi fertilite parametrelerine etkisi. Turk. J. Vet. Anim. Sci., 23: 77-81.

Alacam, E., S. Oszar, C. Kilicoglu, B. Guven, H. Izgur, T. Tekeli and P. Glatzel, 1985. Induction of oestrus in Saanen goats at early breeding season by intravaginal progesterone sponges (MAP) or by prostaglandin $\mathrm{F}_{2} \alpha$ injections. Effect on different age groups. Theriogenology, 24: 283-291.

Atti, N., M. Theriez and L. Abdennebi, 2001. Relationship between ewe body condition at mating and reproductive performance in the fat-tailed Barbarine breed. Anim. Res., 50: 135-144.

Bionaz, M., E. Trevisi, L. Calamari, F. Librandi, A. Ferrari and G. Bertoni, 2007. Plasma paraoxonase, health, inflammatory conditions and liver function in transition dairy cows. J. Dairy Sci., 90: 1740-1750.

Cam, M.A. and M. Kuran, 2004. GnRH agonist treatment on day 12 post-mating to improve reproductive performance in goats. Small Ruminant Res., 52: 169-172.

Ceylan, A., I. Serin, H. Aksit, K. Seyrek and C. Gokbulut, 2007. Dol tutmayan ve anostruslu sut ineklerinde vitamin A, E, beta-karoten, kolesterol ve trigliserid duzeylerinin arastirilmasi. Kafkas Univ. Vet. Fak., 13: 143-147.

Downing, J.A. and R. J. Scaramuzzi, 1991. Nutritient effects on ovulation rate, ovarian function and the secretion of gonadotropic and metabolic hormones in sheep. J. Reprod. Fertil., 103: 137-145. 
Eckerson, H.W., M.C. Wyte and B.N. la Du, 1983. The human serum paraoxanase/arylesterase polymorphism. Am. J. Hum. Genet., 35: 1126-1138.

Hussain, O., H. Waldeland, O. Havrevoll, L.O. Eik, O. Andresen and I.V. England, 1996. Effect of type of roughage and energy level on reproductive performance of pregnant goats. Small Rumin. Res., 21: 97-103.

La Du, B.N., M. Aviram, S. Billecke, M. Navab, S. PrimoParmo, R.C. Sorenson and T. Standiford, 1999. On the psychological role(s) of the paraoxanase. Chem.-Biol. Interact, 14: 119-120.

Madani, T., F. Chouia and K. Abbas, 2009. Effect of oestrus synchronization and body condition on reproduction of anoestrus Ouled Djellal ewes. Asian J. Anim. Vet. Adv., 4: 34-40.

Mellado, M., L. Cantu and J.E. Suarez, 1996. Effects of body condition, length of breeding period, buck: Doe ratio and month of breeding on kidding rates in goats under extensive conditions in arid zones of Mexico. Small Rumin. Res., 23: 29-35.

Mellado, M., R. Valdez, J.E. Garcia, R. Lopez and A. Rodriguez, 2006. Factors affecting the reproductive performance of goats under intensive conditions in a hot arid environment. Small Rumin. Res., 63: 110-118.

Mellado, M., R. Valdez, L.M. Lara and J.E. Garcia, 2004. Risk factors involved in conception, abortion and kidding rates of goats under extensive conditions. Small Rumin. Res., 55: 191-198.

Meza-Herrera, C.A., D.M. Hallford, J.A. Ortiz, R.A. Cuveas and J.M. Sanchez et al., 2008. Body condition and protein supplementation positively affect periovulatory ovarian activity by non LH-mediated pathways in goats. Anim. Reprod. Sci., 106: 412-420.

Miura, H., S. Kotani, M. Kohiruimaki, H. Ohtsuka, M. Kikuchi and Y. Ohnami, 2008. Relationships between the conception rate of estrus synchronization using estradiol benzoate and CIDR (Progesterone) and other parameters in Holstein lactating dairy cows. J. Reprod. Dev., 54: 214-216.

Molina, A., L. Gallego, A. Torres and H. Vergara, 1994. Effect of mating season and level of body reserves on fertility and prolificacy of Manchega ewes. Small Rumin. Res., 14: 209-217.
Oliveira, M.A.L., S.I. Guido and P.F. Lima, 2001. Comparison of different protocols used to induce and synchronize estrus cycle of Saanen goats. Small Rum. Res., 40: 149-153.

Robinson, J.J., 1990. Nutrition in the reproduction of farm animals. Nutr. Res. Rev., 3: 253-276.

Samarutel, J., K. Ling, A. Waldmann, H. Jackson, T. Kaart and A. Leesmae, 2008. Field trial on progesterone cycles, metabolic profiles, body condition score and their relation to fertility in Estonian Holstein dairy cows. Reprod. Dom. Anim., 43: 457-463.

Turk, R., D. Juretic, D. Geres, A. Svetina, N. Turk and Z. Flegar-Mestric, 2008. Influence of oxidative stress and metabolic adaptation on PON1 activity and MDA level in transition dairy cows. Anim. Reprod. Sci., 108: 98-106.

Turk, R., D. Juretic, D. Geres, N. Turk, B. Rekic, V. SimeonRudolf and A. Svetina, 2004. Serum paraoxanase activity and lipid paramaters in the early postpartum period of dairy cows. Res. Vet. Sci., 76: 57-61.

Turk, R., D. Juretic, D. Geres, N. Turk, B. Rekic, V. SimeonRudolf, M. Robic and A. Svetina, 2005. Serum paraoxanase activity and in dairy cows during pregnancy. Res. Vet. Sci., 79: 15-18.

Uslu, B.A. and F. Gulyuz, 2009. Erken anostrus doneminde renkli tiftik kecilerinde intravaginal suunger, CIDR-G ve kulak implanti uygulamalarini takiben $\mathrm{GnRH}$ enjeksiyonunun fertilite uzerine etkisi. Kafkas Univ. Vet. Fak., 15: 385-390.

Valocky, I. and J. Posivak, 1998. Dynamics of some biochemical parameters in the blood serum of sheep in the period of synchronization treatment and on the days of observation after insemination. Czech. J. Anim. Sci., 43: 551-555.

Veliz, F.G., C.A. Meza-Herrera, M.A. de SantiagoMiramontes, G. Arellano-Rodriguez, C. Leyva, R. Rivas-Munoz and M. Mellado, 2009. Effect of parity and progesterone priming on induction of reproductive function in Saanen goats by buck exposure. Livest. Sci., 125: 261-265.

Westwood, C.T., I.J. Lean and J.K. Garvin, 2002. Factors influencing fertility of Holstein dairy cows: A multivariate description. J. Dairy Sci., 85: 3225-3237.

Whitley, N.C. and D.J. Jackson, 2004. An update on estrus synchronization in goats: A minor species. J. Anim. Sci., 82: E270-E276. 